\title{
THE CHALLENGE OF THE POETIC: CRITICISM IN SEARCH OF THE REAL. WITH A DEBT TO BOB VAN REETH, 1975-1985
}

\author{
Sebastiaan Loosen
}

Éditions de la Faculté d'Architecture La Cambre Horta de l'Université libre de Bruxetles «CLARA»

2020/1 nº 7 | pages 106 à 121

ISSN 2295-3671

Article disponible en ligne à l'adresse :

https://www.cairn.info/revue-clara-2020-1-page-106.htm

Distribution électronique Cairn.info pour Éditions de la Faculté d'Architecture La Cambre Horta de l'Université libre de Bruxelles.

(C) Éditions de la Faculté d'Architecture La Cambre Horta de l'Université libre de Bruxelles. Tous droits réservés pour tous pays.

La reproduction ou représentation de cet article, notamment par photocopie, n'est autorisée que dans les limites des conditions générales d'utilisation du site ou, le cas échéant, des conditions générales de la licence souscrite par votre établissement. Toute autre reproduction ou représentation, en tout ou partie, sous quelque forme et de quelque manière que ce soit, est interdite sauf accord préalable et écrit de l'éditeur, en dehors des cas prévus par la législation en vigueur en France. Il est précisé que son stockage dans une base de données est également interdit. 
Abstract As the 1970 witnessed a growing concern for social issues, which were not addressed by most of post-war modernist projects, architects and intellectuals proposed various approaches to claiming a social engagement in architecture. As these attempts to connect with a social agenda often put the notion of architecture's autonomy under strain, likewise pleas for a more engaged public debate seemed to question the autonomy of architectural discourse. This paper discusses one particular trajectory in the history of architectural criticism that aimed to resist such an opposition and defended the public merit of an autonomous notion of architecture. It does so by pointing to and interpreting the consequences of an argumentative shift subtending the self-understanding of criticism in Flanders, roughly from the mid1970 s to the mid-1980s. This shift involves the postulate of "the real" as a wilfully and strategically used category and revolved around the understanding that the essence of architecture is inexpressible in language. On the basis of such understanding, "the poetic" then became a model to deal with these limits of language and was presented as the challenge for both architecture and architectural criticism. As this shift is more a shared understanding than an individual affair, this paper focuses on the symbiotic relation of architect bOb Van Reeth (born 1943) and critics Geert Bekaert (1928-2016) and Mil De Kooning (born 1955) to trace the genesis of this postulated category, rather than delimiting the scope by discussing a single critic or journal.

Sebastiaan Loosen recently obtained his $\mathrm{PhD}$ at the KU Leuven with a dissertation titled Shaping Social Commitment. Architecture and Intellectuality in the 1970 s and 1980s (2019). Part of a broader project on the formative years of architectural theory in Belgium (conducted with Elke Couchez, Hilde Heynen, Rajesh Heynickx, and Yves Schoonjans, and funded by the FWO, The Research Foundation Flanders), it focuses on the various vantage points from which "the social" was addressed in architectural thought. $\mathrm{He}$ recently co-organized the international conference Theory's History, 196X-199X: Challenges in the Historiography of Architectural Knowledge (Brussels, February 2017).

\section{doi.org/10.3917/clara.007.0106}




\section{The Challenge of the Poetic: Criticism in Search of the Real. With a Debt to bOb Van Reeth, 1975-1985}

As the 1970 witnessed a growing concern for social issues, which were not addressed by most of post-war modernist projects, architects and intellectuals proposed various approaches to claiming a social engagement in architecture. As these attempts to connect with a social agenda often put the notion of architecture's autonomy under strain, likewise pleas for a more engaged public debate seemed to question the autonomy of architectural discourse. This paper discusses one particular trajectory in the history of architectural criticism that aimed to resist such an opposition and defended the public merit of an autonomous notion of architecture. It does so by pointing to and interpreting the consequences of an argumentative shift subtending the self-understanding of criticism in Flanders, roughly from the mid1970 s to the mid-1980s. This shift involves the postulate of "the real" as a wilfully and strategically used category and revolved around the understanding that the essence of architecture is inexpressible in language. On the basis of such understanding, "the poetic" then became a model to deal with these limits of language and was presented as a challenge for both architecture and architectural criticism. As this shift is more a shared understanding than an individual affair, this paper focuses on the symbiotic relation of architect bOb Van Reeth (born 1943) and critics Geert Bekaert (1928-2016) and Mil De Kooning (born 1955) to trace the genesis of this postulated category, rather than delimiting the scope by discussing a single critic or journal.

\section{Introduction}

According to Geert Bekaert's account of the history of Belgian architecture, it was in 1983 that a new generation - one of "Bright Young Gods" - announced itself after a long, unproductive period with only few notable projects (Bekaert, 1995: 194). Bekaert was referring to an unbuilt design for the Carrefour de l'Europe in Brussels by Team Hoogpoort. In elaborating this claim, Christophe Van Gerrewey saw the main characteristic of the set of ideas undergirding this design team's approach lying "not only in a definition of reality [...] but in the wilful and strategic use of this word" (Van Gerrewey, 2014: 448). If this timely emergence of "the real" as a strategically used category indeed signals something of a turning point for architectural culture in the 1980s, as well as for architectural criticism, it is worth considering it as a historical phenomenon in its own right.

To this aim, this chapter turns to the decade preceding the date marked by Team Hoogpoort's design, looking into how and why the notion of "the real" was mobilized in relation to architecture and was instrumental in reconfiguring the terms of architectural criticism. In particular bOb Van Reeth's work - and, even more, his 
attitude - evidences how the category of "the real" came about as a fruitful line of thought serving as an antidote to an all-too dogmatic form of post-war modernism. The eloquence of Van Reeth, combined with the intellectual energy his critics invested in his work - besides Bekaert and De Kooning, also historian Francis Strauven (born 1942) was an important supporter of Van Reeth -, resulted in a remarkable symbiosis aimed at developing an impetus for an architectural culture "rooted in the real" (Van Gerrewey, 2011).

Tellingly, in Bekaert's account, the decade in question - the mid-1970s to the mid1980 - was cast as a lost decade that could easily have been skipped and which was only of historical interest as an incubation period, bearing fruit only after 1985 (Bekaert, 1995: 177). Occasionally, Bekaert stated that there was so little for the critic to write about, that critics would cling on to each flicker of inspiration that manifested itself. Those rare flickers - and the hope for the future - were often recognized in the figures of bOb Van Reeth and Charles Vandenhove. An equally meagre portrait could be sketched of Belgian architectural criticism in this period. After $L a$ Maison/Environnement had ceased publication in 1971, Belgium had no major architectural journal until A+ was founded in 1973 - the latter being remembered as a rather mediocre journal for criticism in those days (Delbeke, 2006: III). In an early appreciation, Bekaert even indicated that $A+$ was more an obstacle than a help for critical thinking, "making an advancement and exchange of ideas systematically impossible" (Bekaert, 1983a: 13). In such a climate, the decade that for Bekaert was only of historical interest as the incubation period for an architecture to come could also be considered the same for architectural criticism. This paper traces this period up to the notion of "commonplace", introduced by Bekaert in the mid-1980s and occupying a central position in Flanders' architectural criticism for several decades.

Rather than a single paradigm leading the way - be it science, class struggle, participation, or typology - this impetus relied on the acknowledgement of an essential ignorance, in the sense of something that cannot be known. As an essential "not-knowing", this notion of an epistemological void, core to and skilfully woven into the discourse of Van Reeth and his critics, gradually took the form of postulating "the real" as something fundamentally out of reach of human knowledge.

Many of the motivations and questions underlying this shift towards "the real" resonate with a broader, international evolution of architectural criticism. Reflecting on criticism's history, Jacques Lucan suggested to interpret the 1970 s as a decade traversed by an unease (une inquiétude) with regard to language, which helped reinvigorate architectural criticism (Lucan, 2009: 114, 118). In line with that interpretation, the postulate of "the real" and the accompanying recognition of a "poetic challenge", as a way of coping with that unease, will be considered here as an attempt to foster that linguistic unease as the "vocation" of architectural criticism. As Bruce Robbins argued, with each vocation also comes an appeal to some form of public value (Robbins, 1993: 25; see also: Leach and Moulis, 2010). Hence, rather than seeing this period as an intellectually dead landscape, and parallel to Bekaert's own historiographic interest in the decade, this paper regards it as an "incubation period" by analysing the evolution of this "vocational" aspect - the implicit appeal to a public value - as made manifest in the reflections engendered by Van Reeth's work.

This shift in self-understanding was connected to contemporaneous developments abroad, not only in its linguistic unease, but also with regard to discussions on realism. Well-known intellectuals such as Manfredo Tafuri, Aldo Rossi, Roland Barthes, and Jean Baudrillard directly or indirectly fed these discussions. Despite the large influence of these debates and authors on Bekaert, the approach taken here in historicizing criticism, consists not in uncovering his intellectual references, but in prioritizing the relation to Van Reeth's work. This is informed not only by his own understanding of criticism as a confrontation with a work in its unicity (see also: Jannière, 2009: 136), but also by Van Gerrewey's description of Bekaert's intellectual regime (Van Gerrewey, 


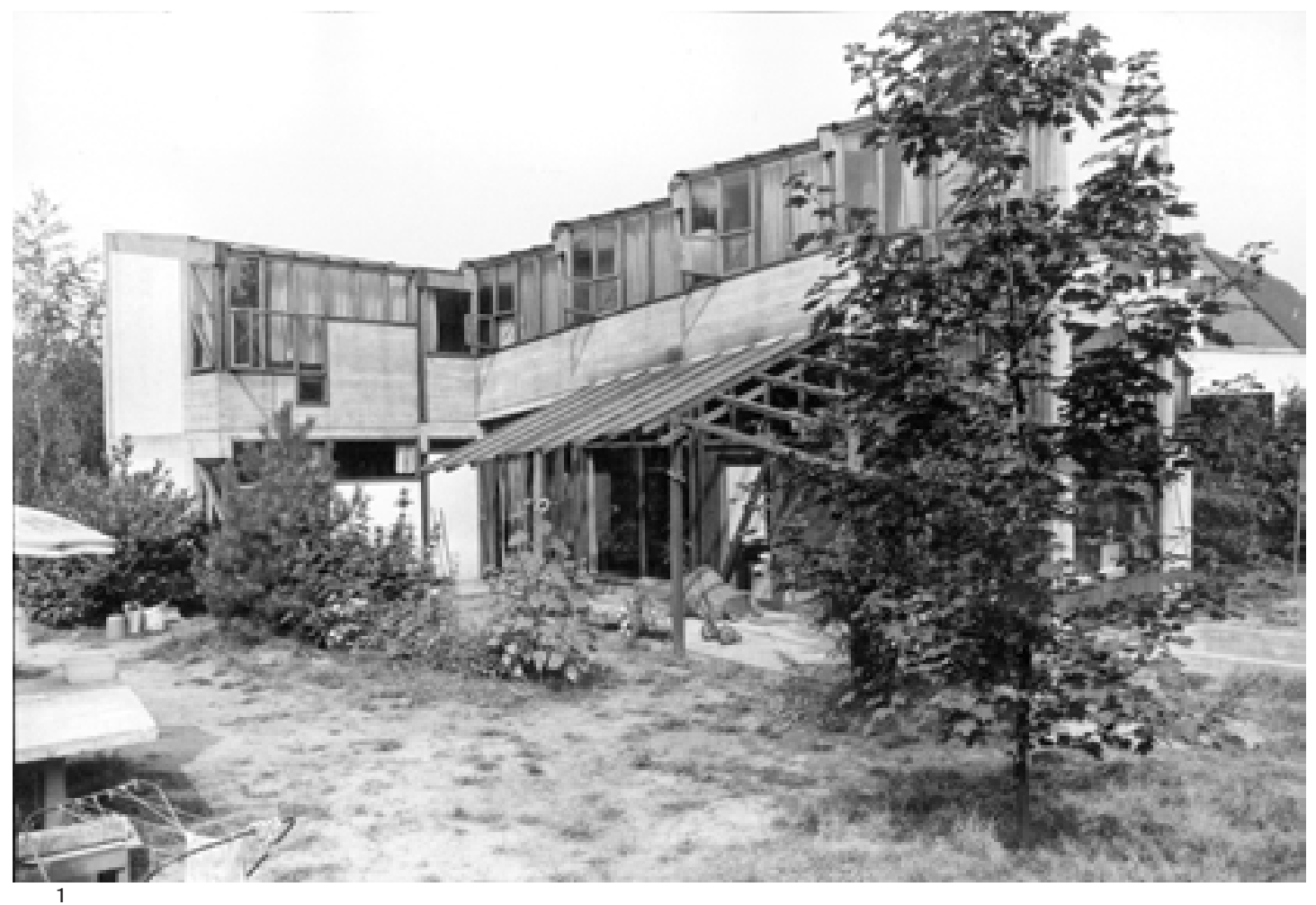

Fig.1

Botte house, Mechelen, 1969-1971. Photographer unknown. Source: Collection Flanders Architecture Institute, Collection Flemish Community, archives bOb Van Reeth and AWG. Courtesy bOb Van Reeth.

Fig. 2

Van Reeth's converted old Beguine convent dwelling, Mechelen, 1969-1970.

Photographer unknown. Source: Collection Flanders Architecture Institute, Collection Flemish Community, archives bOb Van Reeth and AWG. Courtesy bOb Van Reeth.

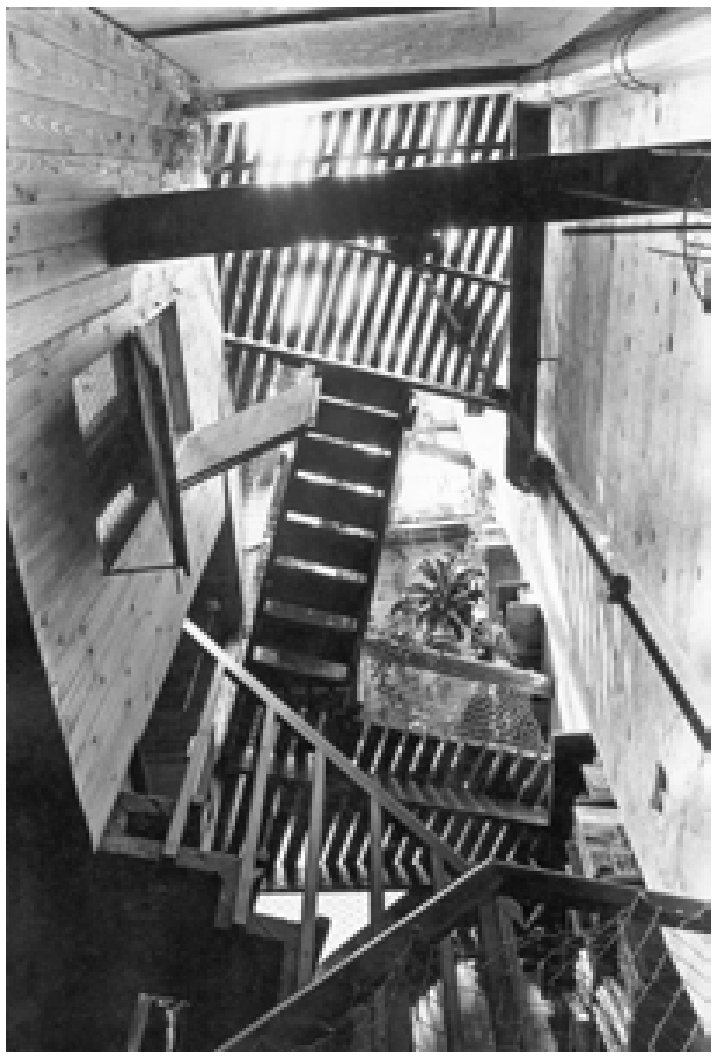


2015: 11-36). Influenced by the spiritual exercises of Ignatius of Loyola impressed upon him during his Jesuit formation, for Bekaert, each confrontation with a work invites one to think it through personally, and potentially provokes a change of perspective, even if slight (ibid.: 15). In short, it was only in confrontation with the concrete architecture of someone as Van Reeth that Bekaert, and more generally his contribution to architectural criticism in Flanders, incorporated these international influences and was able to advance a personal line of thought.

\section{bOb Van Reeth, the paradigmatic architect}

The early work of bOb Van Reeth - the given name being stylized with a middle capital since early on in his career - in many ways embodied the widespread criticism of postwar modernism, opposing all too dogmatic principles with a DIY-mentality and on-thespot intuition, lauding the "back room architecture" of informal outhouse-additions, and being involved in the activity of inner city advocacy groups, which revalued the existing cities. In some accounts, he even figured as the personification of the renewed social engagement of a new generation of architects (Hooghe and Jooris, 1999: 109-110). Not only did he epitomize the freshness of a wide-spread counter-cultural attitude of the new generation, but this attitude also was complemented with a professional proficiency and a clear evolution in his work: from embracing the unfashionable and virtually ignored Flemish vernacular in the early 1970s, he evolved towards a more controlled and historically informed formal language. And when his career was seen as "paradigmatic of the evolution of architecture in the second half of the twentieth century" (Bekaert, 2000: 13), it provides the perfect source material to trace the reconfigurations of architectural criticism throughout this period.

When reviewing the criticism on Van Reeth's work, the established narrative of his "paradigmatic" career entails at least three phases. ${ }^{1}$ Of particular relevance in relation to architectural criticism is the shift from the first to the second phase, since it was then that Van Reeth's approach was dissociated from the mark of "alternative" architecture - confining it to the margins of the discipline - and was considered to successfully engaging with the mainstream as well. On the one hand, the conversion of an old Beguine convent dwelling for the architect's own use (1969-1970), as well as the Botte house (1969-1971), both in Mechelen (Fig.1-2), are representative of the first phase in his career, lauded for its "critical distance to classical functionalism" (Verschaffel, 2013: 51) and roughly spanning the late 1960 s to the early 1970s. On the other hand - and epitomising the second phase of Van Reeth's work in the late 1970s - the Jesuit college in Antwerp (constructed 1977-1978, design initiated 1973), with its historicist references, is generally considered as a confirmation of his proficiency, where his initial intuitions are refined into a more controlled formal language. (Fig.3)

In the first proper retrospective publication on Belgium's post-war architecture, by Bekaert and Francis Strauven, Van Reeth received an honourable mention in the final paragraphs, expressing the hope for the future of architecture in Belgium (Bekaert and Strauven, 1971: 74). Together with Bruno Albert's, Van Reeth's architecture was placed in the trail of Marc Dessauvage, Charles Vandenhove, and André Jacqmain, all being praised for breaking out of the typological and programmatic constraints and developing forms that are able to accommodate any human program. In later years this is identified by critic Mil De Kooning as the constantly recurring preoccupation in Van Reeth's work, namely "the study of the problematic relation between dwelling and

1 In general, the historiography on Van Reeth shows a high degree of analytical repetition, most likely due to the combination of Bekaert's intellectual dominance and his exceptional interest in Van Reeth. See in particular the more succinct presentations of Van Reeth's work, though each with different accents (Dubois, 1991: 23-24; Bekaert, 1995: 153-159; T'Jonck, 1999; Strauven, 2003). 


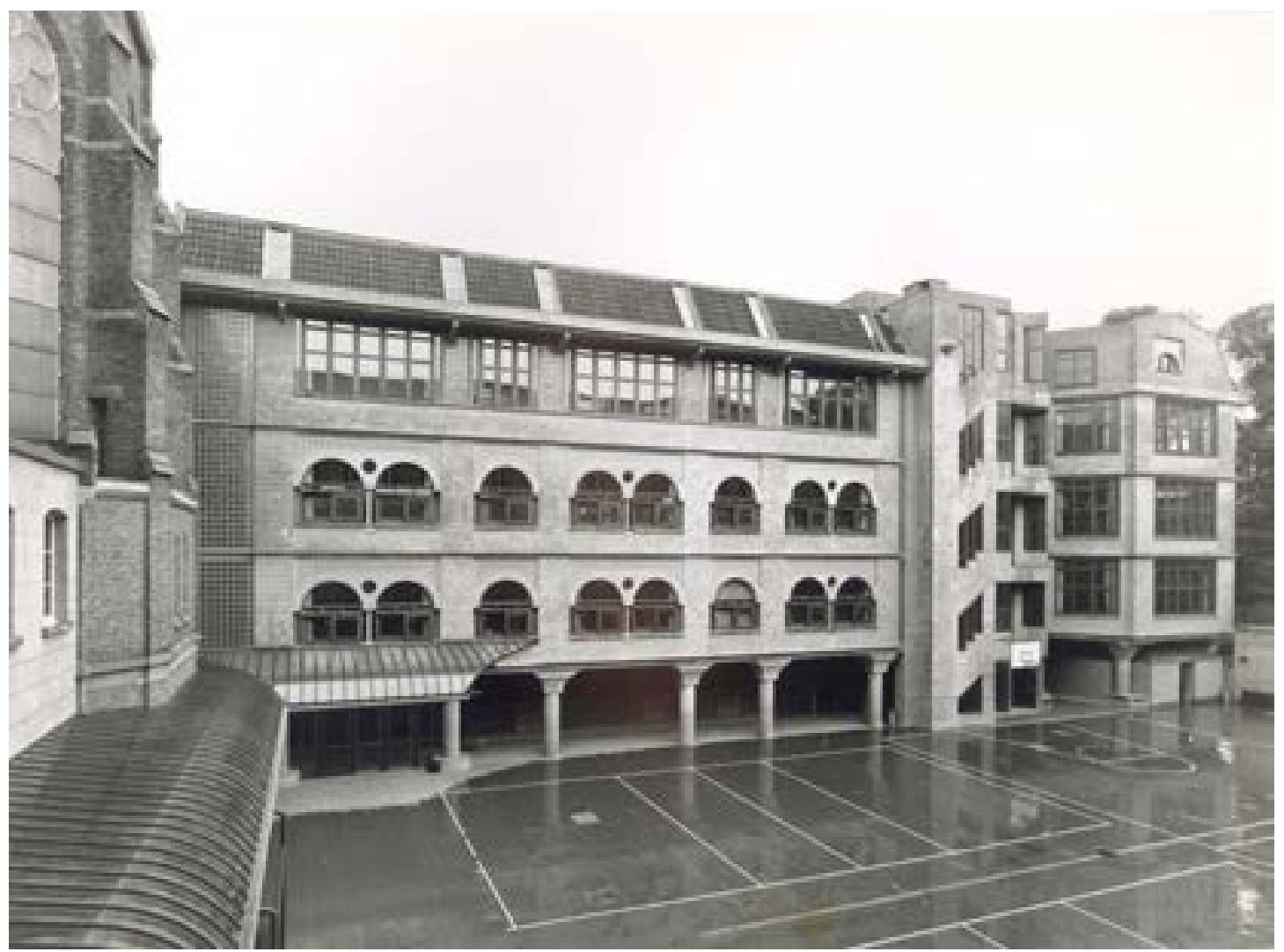

Fig. 3 Onze Lieve Vrouwe Jesuit college, ttdesign initiated 1973 , built 1977-1978. Photographer unknown. Source: Collection Flanders Architecture Institute, Collection Flemish Community, archives bOb Van Reeth and AWG. Courtesy bOb Van Reeth. 
architecture" (De Kooning, 1989: 72). More specifically, this preoccupation concerned the interaction between the structure that architecture provides, and the spontaneous, undetermined life that can unfold within that structure. This is considered "problematic" by De Kooning in the sense that in the inevitable gap between architecture and its inhabitation, architecture cannot be seen as being simply derived from, but rather as a precondition of inhabitation (ibid.). In that sense, there is a fundamental "otherness" to architecture vis-à-vis human existence, since architecture poses its own rules without curtailing the freedom of dwelling. Thus, in Van Reeth's way of accommodating the spontaneity of life, architecture's autonomy is firmly acknowledged. The general consensus amongst his early commentators is that throughout his career, Van Reeth time and again skilfully knew how to balance structure and freedom, gradually fine-tuning this balancing skill into a more controlled formal language. The challenge for criticism then lay in describing how the architect managed to find this balance.

\section{Approaching the real}

When in the mid-1970s, Van Reeth's work was becoming strikingly dissimilar to his earlier work, commentators stressed how little his architecture had to do with "style" and all the more with an architectural “approach". The shift in Van Reeth's architecture was seen as a more controlled use of architectural form, combined with a heightened sense of contextuality - the ability to read and respond to the potential of the site (Strauven, 1980: 45; Bekaert, 1995: 156). Hence the attention was redirected from the architect's built cuvre to his way of approaching his assignment. This was at stake in Bekaert's first monographic text on Van Reeth, published in the Dutch structuralists' journal Forum in 1977 and of great significance to the later reception of his career (Van Gerrewey, 2015: 107-114). After offering a description of the architect's own house, the critic noted that "... we are actually not concerned with this house but with the approach to architecture that is at the bottom of it: the sensory specificity of living in a house is the only base to work from" (Bekaert, 1977: 19).

Thus, notions such as "attitude" and "approach" became key words for criticism to positively describe an architecture that is open to the whole of present-day culture. This entailed giving more weight to the moment of interpretation on the side of the architect: good architecture required the architect not only to display an exceptional receptiveness towards the existing conditions, but also, more actively, to perform a creative, and decisive, act of interpretation (Bekaert, 2000: 11). For instance, one of Van Reeth's later projects was lauded for its "intrinsic power of expression, rooted in a novel vision on or interpretation of our contemporary urban reality and in a passionate faith therein" (ibid.: 13). In other words, in order to avoid receptiveness leading to a conservative, uncritical architecture that merely reproduces that what exists, a more "decisionist" view of design was put in place, one that drew attention to the inevitable moment of decision required to interpret and intervene in reality. It is worth noting that this "decisionist" view of design was central in Bekaert's later exegesis of Aldo Rossi's design theory (Bekaert, 1986: \$5).

\section{The critic in the limelight}

This shift of perspective also had repercussions for criticism itself. When the discussion shifted from the architectural object to the moment of interpretation, the intellectual activity of the architect and that of the critic began to find more common ground - not so differently from how in Rossi's work the difference between history and design dissolves. Since the decisive moment of the creative act might not always be entirely clear to the creators themselves, the critic can join in to make that moment explicit. Both Van Reeth and Charles Vandenhove recognized as much when saying that Bekaert "makes explicit what in my own mind lies expressed much less clearly" (Van Reeth, 1985). Hence it is no coincidence that during the 1980 s the critic was more and more put on a par with the architect, and that the relation between the two was arguably more symbiotic than in preceding decades. When the critic stops 
Fig. 4 Announced, but unrealized Vlees en Beton $n^{\circ} 7$ issue, themed "Who is Bekaert". Engraving by Giuseppe Maria Mitelli. Source: Vlees en Beton, $n^{\circ} 4$, 1985: n.p. Courtesy Mil De Kooning - Vlees en Beton.

\section{vlees en beton}

7

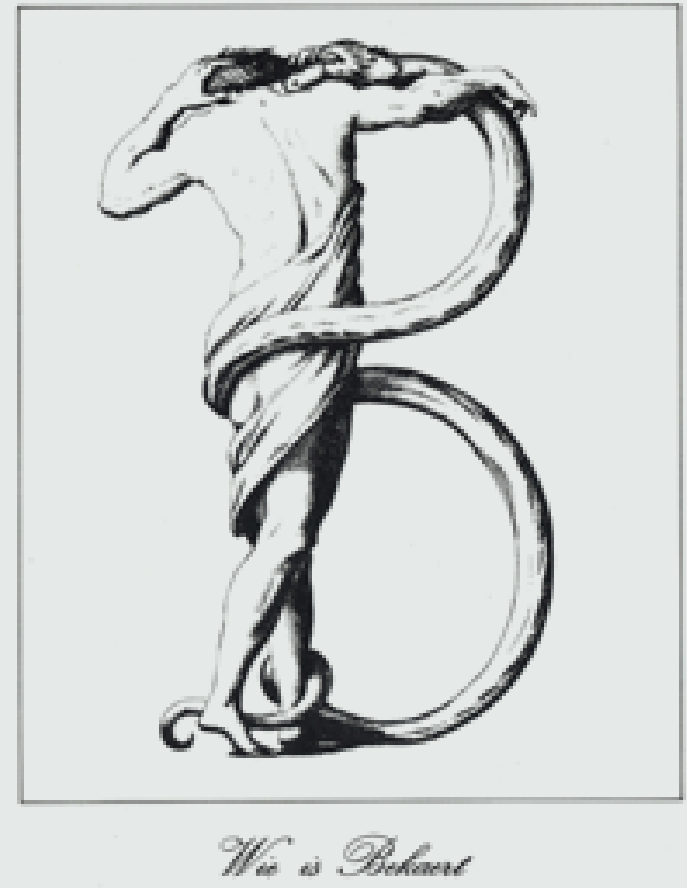

1986 merely judging the architectural object and starts thinking along with the architect how the given conditions could have been interpreted and could have led to a new creation, they become somewhat "brothers in arms" in the joint venture of architecture, yet employing different means.

This symbiosis manifested itself in architect and critic taking up each other terms and insights, to the extent that the written and built cuvres of Bekaert and Van Reeth overlapped. Bekaert served as ghost writer to Van Reeth's inner-city advocacy group Krokus (named after the early-blooming crocus flower) and played an important role in Van Reeth receiving the commission for the Jesuit college in Antwerp (Van Reeth would also build Bekaert's residence). More importantly, their collaborations led to a mutual appropriation of each other's thought: the architect would appropriate the terms of his critics (Van Reeth, 1983, 1985; Koerse, 1995: 16-26), whilst the critic would - in addition to being challenged by his architecture - take the architect's love for Bob Dylan and for paradoxical aphorisms seriously (Bekaert, 1977, 1987a).

Both bOb Van Reeth and Geert Bekaert, as well as their symbiotic relation, were central to the publishing efforts undertaken by Mil De Kooning at the University of Ghent in the 1980s. De Kooning was instrumental in compiling Van Reeth's writings, anthologising Bekaert's essays, and launching the journal Vlees en Beton ("Flesh and Concrete"), presumably a pun on the proverb "of flesh and blood" to point to architecture's fundamental role in human existence (Van Reeth 
and Bekaert, 1983; Bekaert, 1985-2012). The second issue of Vlees en Beton, which appeared in 1985 as " $\mathrm{n}^{\circ} 3$ " - whereas " $\mathrm{n}^{\circ} 1$ " was a fictitious issue -, served as the catalogue of an exhibition on the work of Van Reeth's architectural group, and contained an extensive interview with Bekaert by De Kooning. Remarkably, rather than dealing with Van Reeth's work, the interview focused on Bekaert's own work as a critic, and is perhaps one of the first documents in the historiography of Belgian criticism - besides the occasional obituary - where the work of the architectural critic is considered to be a worthy topic in its own right (De Kooning, 1985a) (Fig. 4). That particular issue of Vlees en Beton not only contained an interview with Bekaert, but also one with the architect himself. When reading both interviews together, it is striking to note how many passages are interchangeable and, therefore, how much the intellectual work of the "brothers in arms", critic and architect, resembled each other.

\section{"As one speaks..."}

What was considered positive as an approach, for both architect and critic, had much to do with a sense of unease - in Jacques Lucan's terms - with regard to language. Not merely seen as an intellectual reflection, this unease was considered to produce real effects, especially with regard to the state of architectural discussion.

Testimony to this was Vlees en Beton's first issue, containing an intense polemic about the site of the obsolete nineteenth-century Saint-John Hospital in Bruges and how it had been presented in public media (De Kooning and Van Reeth, 1984). De Kooning argued that, with Groep Planning, the wrong architect had been commissioned and that the project by Marc Dessauvage was clearly much better - a view shared by Van Reeth and Bekaert. In his piece, De Kooning argued that this wrong choice was partly due to the failure of public media to allow for a proper discussion: the newspaper $D e$ Standaard ("The Standard") had provided extensive space to Groep Planning's Jan Tanghe's argumentation, whilst Bekaert's defence of Dessauvage had barely made the newspaper's pages. Even if the hospital site's future had generated plenty of discussion, according to De Kooning most voices - and Tanghe's in particular - were simply ignoring each other's arguments, thus failing to engage in a proper discussion on architecture. Frustrated by this lack of a proper discussion - despite the numerous writings on the site's future - De Kooning noted of this state of affairs that "not so much the contradiction as the exchangeability of the arguments is the most remarkable aspect of these chains of argumentation. Words, terms, notions; noble or coarse: worn out currency that communicates nothing, and yet presupposes communication"2 (De Kooning, 1984). Failing to engage in a proper discussion on architecture, language was for De Kooning being stripped of its communicative function, and a wrong choice on the future of the hospital site in Bruges was the very tangible outcome of this fact.

This perceived failed communication was only the symptom of a more profound unease, which was also sensed by Van Reeth and which lay at the heart of his love for paradoxical aphorisms: "remembering what never occurred", "doing the same, always different", "architects should construct ruins", are only a few of those. On the occasion of Van Reeth's sixty-fifth birthday, Bekaert affectively called the architect a "born oxymoron" (Bekaert, 2012) and, earlier, he pointed out how these paradoxes are generated by the thought and language in which architecture is caught (Bekaert, 2000: 7). In Van Reeth's indulging in paradoxes lingers the intuition to foster an unmediated and pre-linguistic experience against the disturbing factors of thought and language. Thus, architecture is framed as part of a more general critique of culture in order to retrieve a sense of immediacy with the real, understood as a lived experience not yet captured in a logic of representation. For the same

2 Original: "Maar niet zozeer de tegenspraak dan wel de verwisselbaarheid van argumenten is het meest opvallende kenmerk in deze redeneerketens. Woorden, termen, begrippen; nobel of platvloers: versleten munten die niets meedelen en toch kommunikatie vooronderstellen." 
reason, De Kooning (1985b) highlighted Van Reeth's aphorism "as one speaks, one violates reality", as a welcome hesitation to reducing the fragile reality to the discursive zone of existence. As a further variation on the balance between structure and freedom, earlier identified in Van Reeth's architecture, the challenge for criticism then lies in coping with the violent, yet inevitable, representations by which we mediate our relation to the world.

\section{Postulating the real}

Before considering how international debates reverberated in these discussions, it is important to highlight how for Bekaert, more than arguments found in books and journals, it was the confrontation with architecture such as Van Reeth's that prompted such reflections. Bekaert's various texts on Van Reeth of the late 1970s and 1980s, can be seen as attempts to cope with this unease of language and its accompanying critique of culture. His 1977 monographic text on Van Reeth contains many references to the negative side of all things related to representation, abstraction, language and image. Van Reeth's architecture is then credited for going past those forms of representation and somehow being able to get in touch with "the real" and the primordiality of human experience. Juxtaposed to this argumentation are a series of quotes that help validating such a claim: Bob Dylan, Adolf Loos, the poet Paul Van Ostaijen, Michel Foucault, Paul Klee, Rudolf Schindler, Roland Barthes as well as Van Reeth himself. Yet, except for emphasizing the architect's approach rather than the built objects, in this occasion Bekaert did not really reflect on the possibility of a positive theory of representation in the sense of how to cope with the inevitability of representation. Two years later, on the occasion of the inauguration of the Antwerp Jesuit college, Bekaert undertook that effort by seizing the opportunity to push his thoughts a step further. In a remarkable opening speech, he tried to explain how exactly Van Reeth's architecture was able to retrieve a sense of immediacy which other buildings seemed to lack (Bekaert, 1983b). This immediacy figured under the name "concreteness", understood as an ultimate freedom from any sort of system, as something that produces rather than reproduces and that generates meaning rather than merely passing it on. In trying to define such "concreteness" of the building - and as a further articulation of balancing structure and freedom, and of coping with the inevitable representations by which we mediate our relation to the world - the bulk of the speech tests out all kinds of formulations where somehow life takes precedence over the form in which it is comprehended. Bekaert stated for example that "the building poses its own criteria by which it wants to be judged", "spontaneity occurs when the rules are so assimilated in experience that they originate from it time and again", and "there exists a formalism so humble, which doesn't take refuge in the absolute, but conquers itself constantly against the amorphous" (ibid.: 122, 123, 125). After admitting that he could only describe the building with oxymora, he wondered "whether the concreteness of a building, like the concreteness of a poem, isn't an utter illusion in our society" (ibid.: 138). Bekaert claimed that, even if such concreteness to which a building or poem might aspire turns out to be an illusion, it is one that cannot be cast aside: "The plea that I've given starts from that assumption; from the faith in the destructive, liberating power of poetry. The plea can best be forgotten as soon as possible. The building exists" (ibid.: 139). Although Bekaert saw it impossible to deliver a positive theory of representation and was forced into the use of oxymora, it was this very awareness that forced the critic to articulate his presuppositions as clearly as possible, ending up with reducing the building's concreteness to the status of a postulate - something that cannot be known, but needs to be accepted nevertheless.

Bekaert's doubts about such concreteness a building might aspire to - of being closer to the spontaneity of life than our conventions allow to account for - and the concomitant acceptance that the real is something which at most can be postulated in our thinking can count as one of Bekaert's most lucid articulation of criticism's declaration of principles in these decades. It places at the heart 
of architectural knowledge a fundamentally unattainable ideal and, by precluding the possibility of a final word, it makes a strong plea for a permanent debate.

\section{Realisms}

Reflections such as those above were not isolated internationally. By the late 1970s, many architects and thinkers worldwide felt the need to revert to a notion of "the real", often turning it into a plea for some form of realism (Hays, 1998: 246). Rather than lumping these debates together, as if they were all engaging in the same discussion, it seems better to treat them as a rather uneven history of realisms. Michael Hays diagnosed this uneven history of realisms as characterized by "antinomies", pointing to the contradictory position of binding the work of architecture to reality whilst simultaneously claiming its autonomy (1998: 254). In this uneven historical terrain, these "antinomies of realism" have to be decoded within each specific configuration. If we extrapolate Hays' antinomy, the scattered discussions on realism formed an outlet allowing at least two often overlapping positions to emerge: first, a political "activist" position à la Bernard Huet, who showed his appreciation for Socialist Realism, and who presented ARAU's activism in Brussels as an illustration of his plea for realism; and, second, a reading of architecture through linguistic theory as a continuous deferral of signification à la Martin Steinmann, who interpreted the Ticino exhibition in the spirit of Viktor Shklovsky's formalism (Hays, 1998: 246-260). These two positions offer opposing models of intervening in reality: either in a direct manner as in the case of Huet, or, in the case of Steinmann, indirectly, through the repository of history, detached from the actual historical conditions.

Beyond these divergent positions, as represented by Huet and Steinmann, but also including less extreme voices, such as those of Giorgio Grassi and Alan Colquhoun, some have speculated about the reasons for these nuanced reflections on history, reality, representation, and autonomy. In line with Fredric Jameson, Hal Foster argues that 1960 minimalist art's emphasis on the here-and-now and its suspicion about artistic subjectivity were attempts to engage with "a reification of history and a fragmentation of the subject associated since Georg Lukács with the dynamic of capitalism" (Foster, 1996: 62). During the 1970s, still according to Foster, this process of reification and fragmentation continued and affected "the sign", as can be recognized in the works of authors such as Roland Barthes and Jacques Derrida.

Rooted in the experience of a transformed society, common to many Western European countries, indeed Bekaert's speculations on the real are sometimes articulated in a politicized fashion, as an overt attempt to recover, via Rossi and Van Reeth, a "proletarian" dimension of immediacy that had been lost in a bourgeois society (Verschaffel, 1993) - even though this was not translated into a political dimension as straightforward as Huet's headfirst effort. These speculations on realism, in turn led Bekaert to mobilize the concept of "the poetic" (and later that of "the commonplace") as his own, personal way of dealing with Hays' antinomies.

\section{Realist poetics}

Complementary to casting the real as a postulate, the poetic was cast as architecture's challenge. The invoked notion of the poetic refers to more than just poetry: it points to the fundamental dimension of human creativity as does the ancient Greek term poiesis - the creative act of bringing something into being. Thus, the poetic provides a model for architectural creativity, concerning how this creativity relates to the existing world and to our mental constructs of it.

In a 1976 lecture at the THE (Technische Hogeschool Eindhoven $)^{3}$ - the Dutch College of Technology where he was appointed professor in 1973 - and amidst the expanding architectural theoretical activities he and his colleagues were stimulating there, Bekaert elaborated on architecture's poetic function as a means to reflect on architecture's societal meaning and to overcome what

3 The THE was a Dutch college for higher education in technology, known, since 1986, as the TU/e Technische Universiteit Eindhoven (Eindhoven University of Technology). 
he perceived as a false dilemma between two opposite positions and their respective appeals to a societal relevance (Bekaert, 2007: $256^{4}$ ). Personifying these positions were Peter Eisenman and his formalism, and Giancarlo De Carlo, who sought the legitimation for architectural form in a social dimension outside of architecture. Both positions were relegated to a bourgeois understanding of life, against which Bekaert set the poetic as an "eminently anti-bourgeois philosophy of life" (ibid.: 256). Bekaert accused Eisenman (but also Manfredo Tafuri) of incorrectly rendering architecture incapable to offer some form of resistance to the societal processes in which it was already caught. Against such pessimism, Bekaert aimed to recuperate, via the notion of the poetic, a "form of resistance against an interpretation and misuse of reality" (ibid.: 259). In other words, through the notion of architecture's poetic function, Bekaert intended to safeguard a critical role for architecture to intervene in the capitalist logic with which it is entangled and in which it is even complicit. He concluded by stating that "only a realist poetic approach, a poetry operative in historical reality [...] is able to introduce a new approach of reality and hence also a new society" (ibid.: 268).

Central in this view of a "realist poetics" would be the counterpart of the poetic, which by the mid-1980 found an adequate articulation as the commonplace. Defined as an "ordinary, often used expression whose original force is hardly felt anymore" (Bekaert, 1987b quoted from Van Gerrewey, 2011: 92) ${ }^{5}$, the commonplace would be, in Flanders, the articulation of a more widespread turn towards the everyday and the ordinary (Avermaete, 2014). In the interplay between the commonplace and the poetic, the commonplace is not simply a negative term, serving as the backdrop to flickers of poetic intervention: it also contains its own positive characteristics as it protects us from

4 This 1976 lecture should not be confused with the homonymous text written in 1986 and published in 1988, which retakes several of its themes in a somewhat more lighthearted fashion. "a confrontation with the bottomlessness of our existence" (Heynen, 1993: 15). In the intensification of the commonplace in a poetic dimension lies the leeway for a meaningful architectural intervention: "it turns the commonplace into an interesting experience, it digs up some of its original force, with lots of irony" (Bekaert, 1987b quoted from Van Gerrewey, 2011: 96). Again, Van Reeth's work is illustrative of this interplay. About the architect's house in Mechelen, for instance, Bekaert noted how "all interventions are focused on discovering the rich possibilities of the stereotypical dwelling, freed from its crusted layers of meaning, to cast light on its actual, inner reality" (Bekaert, 2000: 17).

\section{Poetic criticism vs. public debate}

In analyses such as those above, not only does the model of the poetic suggest the structure of the architect's creativity, but also that of the critic. At the beginning of the 1980s, Bekaert extended his investigations of the notion of the poetic by confronting it with a long history of the guises under which "the social" appeared in architecture, by reaching back to authors such as De l'Orme, Laugier, Viollet-le-Duc and Adolf Loos - whose work Bekaert was at the same time republishing at Mardaga publishing house (Bekaert, 1981). He emphasized that architecture is a rational construction in that it always involves human thought and that it is human creativity that breathes life into it. As a consequence, history of architecture can only be understood as a poetic happening (ibid.: 17). More specifically, in this genealogy of architecture's social dimension, the poetic was this time mobilized to save architecture from a "bourgeois apriorism of the social" (ibid.). Hence, the challenge of architecture's poetic function for criticism lay in the need to continuously launch new concepts in discussing architecture in order to avoid ending up with a crusted notion of "the social" to which architecture pays lip service. These "offensive concepts are not readily available syntheses, nor universal images of man or society, nor repressed ideals or frustrated utopias. A genuinely poetic concept demolishes these, it shatters them. It has not much use for general ideas 
because it is exactly so extraordinarily concrete, so directly involved in its material and its materiality, like a pigeon fancier plays with his pigeons" (ibid.).

It would not take long before descriptions of the poetic such as the above, would also provide the model to appreciate Bekaert's own work as a critic. Thus, it is along similar lines that De Kooning would recognize in Bekaert the ability to "disclose" the world. In the event of a single text, he argued, Bekaert is not restrained in a closed world of abstractions, but manages to get in touch with the fundamentally unfinished, concrete world (De Kooning, 1985c). And more recently, Van Gerrewey deemed Barthes' term "logo-technicien" adequate to describe Bekaert's intellectual merits: a "founder of language", an intellectual pioneer that ventures in the realm of the non-linguistic - the real - to remodel our way of speaking about it (Van Gerrewey, 2015: 17-36). In this sense, architectural criticism came to a self-understanding that invoked an analogy with the poetic as a model to get in touch with the real, beyond and despite language. In other words, criticism's vocation came to be defined as the challenge of the poetic: coping with the fundamental ignorance $v i s-\grave{a}-v i s$ the real by seeking to transgress the limits of language.

Taking this at heart, Mil De Kooning would make a case for a renewed criticism along these lines in a polemical "call to the population", again revolving around the architecture of Van Reeth. Even if Van Reeth's architecture was generally appreciated by peers and critics, De Kooning nevertheless considered it as mainly being misunderstood. In this regard, he explicitly mentioned the sociologist Sieg Vlaeminck - who had labelled Van Reeth's urban activism with Krokus as "elitist contestation" - and the historian Francis Strauven - who had pointed to the inevitable formalist aspect of Van Reeth's architectural vocabulary. Against these critics, De Kooning staged the exemplary couple Van Reeth-Bekaert in order to dismiss forms of critique operating with preconceived, external criteria (such as "participation", "integration", or "typology"). Instead, he called for a form of criticism - like Bekaert's - that relied more on the intellectual capacities to discover the criteria that the architectural work poses by itself (De Kooning, 1983). Such a call reconfigured the relation between the general public, professional and critical expert. On the one hand, by foreclosing any "final word" on architecture, De Kooning, Van Reeth and Bekaert severely questioned any lasting authority of experts and professionals, hence arguing for an opened, more public debate, not limited to an expert domain. In its most radical form, the notion of expertise became substituted by that of passionate polemics open to anyone who discusses architecture from a personal understanding of reality, compelling the dialogical partners to compare with their own views. Yet, on the other hand, they equally acknowledged that architecture contains a logic of its own. Throughout their writings, the autonomy of architecture came to the fore as a precondition for a flourishing human existence. Therefore, a public debate on architecture should not simply dissolve in a wider societal debate, but should occupy its own platforms and media - open, but specific. The public dimension of this new vocation of architectural criticism lay not so much in a direct engagement with public media as in the qualification of architecture as a cultural phenomenon in its own right. By the late 1980 s - in an interview that prefigures the many initiatives that were to follow in the next decades in Flanders, such as the start of series of biannual yearbooks in 1994, the creation of the office of Flemish Government Architect in 1998, and the founding of the Flanders Architecture Institute in 2001 - Van Reeth, Bekaert, and Strauven would lament the structural lack of the necessary platforms to establish such a shared "architectonic culture" where something of a consensus on architectural quality could come about ( $\mathrm{Six}$, 1987: 56). In such an "architectonic culture", architecture is open for discussion to anyone who is willing to consider it as such, as a cultural phenomenon in its own right - rather than being surrendered to a problematic "outside" of architecture, and the discussion being pursued in, for instance, scientific or political terms. 


\section{Conclusion}

By reviewing one particular branch of criticism's history in Flanders, staged here around the figure and architecture of $\mathrm{bOb}$ Van Reeth and mainly analysed through the writings of Geert Bekaert, this paper builds on Lucan's proposition that the 1970 s brought an unease towards language, productive for criticism. The various writings of Van Reeth, Bekaert and De Kooning show a common affirmation of the primacy of pre-linguistic experience, and an attempt to deal with the epistemic violence inherent in language and any form of representation. In parallel to the evolution in Van Reeth's work towards an understanding of the liberating character of autonomous forms, Bekaert made recourse to the notion of "the poetic" as the mechanism that keeps architecture and its autonomy in tune with a conception of the real, thus offering leeway to an ultimately free subjectivity.

Following Jean-François Lyotard, Lucan further suggests reading this shift as a postmodern transition, one where the architectural project is no longer governed by pre-established rules, but establishes those rules itself time and again (Lucan, 2009: 120). It seems that in this perennial (re-)constitution, architectural criticism found its vocation and that the unease towards language then served as paradoxically grounding and setting the future agenda for a relentless attempt to designate the real.

Already in the early 1990s, Bart Verschaffel pointed to the lasting impact of this category of the real, and suggested that it had substituted an obsolete faith in Truth and Knowledge. "As a guest who once was invited and now refuses to leave - though he is no longer wanted -, the category of the 'real' has remained with us in our thinking on art and architecture" (Verschaffel, 1993: 68). Not unlike Hal Foster's interpretation, Verschaffel suggested to see this widespread fascination with the real as ultimately rooted in an unsatisfied bourgeois mind, marked by the alienating experiences of a society based on specialization. These intellectuals' engagement was interpreted as a longing for the unattainable ideal of a form-of-life without any form of mediation or representation, just like - in the poet Paul Van Ostaijen's terms - "a pigeon fancier holds his pigeons", unconcerned with form or meaning and only concerned with his own life.

Hence, postulating the real in their thinking as something fundamentally out of reach - and, with it, a moment of decisive irrationality at the heart of the discipline - was perhaps the most attainable action in a society where representation is part and parcel of reality and where a direct participation of "the public" in architecture is as illusionary as the intellectual gaining the immediacy of the pigeon fancier. 


\section{REFERENCES}

AVERMAETE, T. 2014. “The Place of Commonplace: The Ordinary as Alternative Architectural Lens in Western Europe", in E.G. Haddad, D. Rifkind (eds.), A Critical History of Contemporary Architecture, 1960-2010, Farnham, Ashgate: 189-206.

BEKAERT, G. 1977. "bOb Van Reeth: The Alibi of the Architecture", Forum, vol. XXVI, n 3: 3-22.

BEKAERT, G. 1981. "Het recht op architectuur" [The Right to Architecture], Wonen/ TABK, $n^{\circ}$ 4: 8-17.

BEKAERT, G. 1983a. "Wie over architectuur wil spreken, sta op, en zwijge: bedenkingen van een buitenstaander, buitenstaanders hebben gemakkelijk spreken" [Whoever Wishes to Talk About Architecture, Stand Up, and Be Silent: Reflections by an Outsider, It Is Easy for Outsiders to Talk], Wonen/TABK, $n^{\circ} 11$ : 8-27.

BEKAERT, G. 1983b. "Afvallig ben ik pas trouw" [As Apostate I Am Even More Faithful], in B. Van Reeth and G. Bekaert, Op. cit.: $115-140$.

BEKAERT, G. 1985-2012. Verzamelde opstellen [Collected Essays], 9 vols. [1985-1986, vols. 1-2 edited by M. De Kooning, H. Stynen, Brussels, Stichting Monumenten- en Landschapszorg; 20072012, vols. 3-9 edited by C. Van Gerrewey, M. De Kooning, Ghent, WZW Editions \& Productions / UGent - Vakgroep Architectuur \& Stedenbouw].

BEKAERT, G. 1986. Het analogon van een proletarische architectuur. Notities voor een artikel over Aldo Rossi [The Analogue of a Proletarian Architecture. Notes for an Article on Aldo Rossi], (Vlees en Beton: 6), Damme, Laat-XX'-eeuws Genootschap voor Architectuur en Stedebouw [English translation in C. Van Gerrewey, (ed.) 2011, Op. cit.: 298-351].

BEKAERT, G. 1987a. "De herinnering aan wat nooit heeft bestaan" [The Memory of What Never Was], in M. De Kooning (ed.), AWG. Inventaris 1965-1987, Kalmthout, Biblio: n.p. [English translation in C. Van Gerrewey (ed.) 2011, Op. cit.: 121-124]. BEKAERT, G. 1987b. "Belgische architectuur als gemeenplaats: de afwezigheid van een architectonische cultuur als uitdaging" [Belgian Architecture as a Commonplace: The Absence of an Architectural Culture as a Challenge], Archis, vol. III, $n^{\circ}$ 9: 10-11 [English translation in C. Van Gerrewey (ed.) 2011, Op. cit.: 90-96].

BEKAERT, G. 1988. Architectuur zonder schaduw/Architecture Devoid of Shadow, Rotterdam, 010 Publishers.

BEKAERT, G. 1995. Hedendaagse architectuur in België, Tielt, Lannoo [Simultaneously published in English as Contemporary Architecture in Belgium, Tielt, Lannoo, and in French as Architecture contemporaine en Belgique, Brussels, Racine].

BEKAERT, G. 2000. A.W.G. bOb Van Reeth architecten, Ghent, Ludion [Simultaneously published in English]
BEKAERT, G. 2007. "Architectuur zonder schaduw" [Architecture Devoid of Shadow], in Verzamelde opstellen, vol. 3: 253-268.

BEKAERT, G. 2012. "Aan bOb Van Reeth. Als oxymoron geboren" [To bOb Van Reeth. A Born Oxymoron], in Verzamelde opstellen, vol. 9: 183-184.

BEKAERT, G.; STRAUVEN, F. 1971. Bouwen in België, 1945-1970, Brussels, Nationale Confederatie van het Bouwbedrijf [Simultaneously published in French as La construction en Belgique, Brussels, Conféderation Nationale de la Construction].

DE KOONING, M. 1983. "Het vermogen tot herkennen: een algemene reflectie en een oproep aan de bevolking" [The Ability to Recognize: A General Reflection and a Call to the Population], $A+, n^{\circ} 81: 36-37$ [Simultaneously published in French]. DE KOONING, M. 1984. "Dichters zien gelijkenissen waar burgers betekenissen willen" [Poets See Similarities Where Citizens Want Meanings], Vlees en Beton, $n^{\circ} 2$ : n.p.

DE KOONING, M. 1985a. "Spreektralie. Geert Bekaert in gesprek" [Speech Grille. Geert Bekaert in Conversation], Vlees en Beton, $n^{\circ}$ 3: n.p.

DE KOONING, M. 1985b. "Herhalen wat nooit gezegd is" [To Repeat What Has Never Been Uttered], Vlees en Beton, $n^{\circ}$ 3: n.p.

DE KOONING, M. 1985c. "De beweeglijke waarheid" [The Moveable Truth], Vlees en Beton, $n^{\circ}$ 3: n.p.

DE KOONING, M. 1989. "Woning Van

Roosmalen" [Van Roosmalen House], A+, $n^{\circ}$ 105: 72-73 [Simultaneously published in French as "Maison Van Roosmalen, Anvers AWG"].

DE KOONING, M.; VAN REETH, B. 1984. "Marc Dessauvage \& bOb Van Reeth in 'Het Verdriet van Brugge' " [Marc Dessauvage \& bOb Van Reeth in 'The Sorrow of Bruges'], Vlees en Beton, $n^{\circ} 2$ : n.p.

DELBEKE, M. 2006. "Architecten en kritiek: bedenkingen bij 200 nummers van A+" [Architects and Criticism: Reflections on $200 \mathrm{~A}+$ issues], $A+, n^{\circ} 200$ : I-IV [Simultaneously published in French as "Les architectes et la critique"].

DOI: https://doi.org/1854/LU-341903 DUBOIS, M. (ed.) 1991. Architetti (della Fiandra)/Architects (from Flanders), Ghent, Stichting Architectuurmuseum. FOSTER, H. 1996. The Return of the Real. The Avant-Garde at the End of the Century, Cambridge (MA), MIT Press [Translated in French as 2005. Le retour du réel. Situation actuelle de l'avant-garde, Brussels, La Lettre Volée].

HAYS, K.M. (ed.) 1998. Architecture Theory since 1968, Cambridge (MA), MIT Press.

HEYNEN, H. 1993. "In New Babylon kan je niet wonen: over het omgaan met poëzie en gemeenplaats" [You Can't Live in New Babylon: On Dealing with Poetry and Commonplace], in H. Heynen (ed.), Wonen tussen gemeenplaats en poëzie. Opstellen over stad en architectuur [Living Between Commonplace and Poetry. Essays on City and Architecture], Rotterdam, 010: 9-23. HOOGHE, M.; JOORIS, A. 1999. Golden Sixties. België in de jaren zestig, 1958-1973, Ghent, Ludion [Simultaneously published in French as La Belgique dans les années soixante].

JANNIĖRE, H. 2009. "La critique architecturale, objet de recherche", in K. Frampton, H. Jannière (eds.), Les Cahiers de la Recherche Architecturale et Urbaine (special issue, "La critique en temps et lieux"), n 24/25: 121-140. DOI: https:// doi.org/10.4000/crau.311 [Eng. transl. 2010. "Architecture Criticism: Identifying an Object of Study", OASE Journal for Architecture (special issue, "Constructing Criticism"), $n^{\circ}$ 81: 33-55. Retrieved from: https://www.oasejournal.nl/en/Issues/81/ ArchitectureCriticismldentifying AnObjectOfStudy [available October 15, 2019] ].

KOERSE, W. 1995. Architectuur is niet interessant. Willem Koerse in gesprek met bOb Van Reeth [Architecture is Not Interesting. Willem Koerse in Conversation with bOb Van Reeth], Antwerp, Hadewijch. LEACH, A.; MOULIS, A. 2010.

"History, Criticism, Judgment, Project", Architectural Theory Review (special issue "On Writing Architecture"), vol. XV, $n^{\circ} 3$ : 298-311. DOI: https://doi.org/10.1080/ 13264826.2010.524305

LUCAN, J. 2009. "Langage de la critique, critique du langage : la transition postmoderne" [Language of Criticism, Criticism of Language. The Postmodern Transition], in K. Frampton, H. Jannière (eds.), Les Cahiers de la Recherche Architecturale et Urbaine (special issue, "La critique en temps et lieux"), $n^{\circ}$ 24/25: 113-120. DOI: https://doi.org/10.4000/crau.309 ROBBINS, B. 1993. Secular Vocations. Intellectuals, Professionalism, Culture, London/New York, Verso.

SIX, G. 1987. "Indian summer in architektuur-land", Knack, n ${ }^{\circ} 44$, November 4 : 54-61.

STRAUVEN, F. 1980. "À la recherche d'un langage perdu: un projet de Charles Vandenhove à Liège, 1979" [In Search of a Lost Language: A Project by Charles Vandenhove in Liège, 1979], Archives d'Architecture Moderne, $n^{\circ} 17$ : 40-47.

STRAUVEN, F. 2003. "Van Reeth, bOb", in A. Van Loo (ed.), Repertorium van de architectuur in België. Van 1830 tot heden [Compendium of Architecture in Belgium From 1830 to the Present], Antwerp, Mercatorfonds: 582-583 [Simultaneously published in French as Dictionnaire de l'architecture en Belgique. De 1830 à nos jours].

T'JONCK, P. 1999. "AWG/bOb Van Reeth", in M. De Kooning (ed.), Horta and After. 25 Masters of Modern Architecture in Belgium, (Vlees en Beton: 39-49), Ghent, University of Ghent: 260-275. DOI: https:// doi.org/1854/LU-116570

VAN GERREWEY, C. (ed.) 2011. Rooted in the Real. Writings on Architecture by Geert Bekaert, (Vlees en Beton: 87), Ghent, 
WZW Editions \& Productions.

DOI: https://doi.org/1854/LU-1938635

VAN GERREWEY, C. 2014. "Amnesty for the City. The Hoogpoort Design for the Carrefour de l'Europe in Brussels (1983)", The Journal of Architecture, vol. XIX, $n^{\circ}$ 3: 435-453. DOI: https://doi.org/ 10.1080/13602365.2014.931330

VAN GERREWEY, C. 2015. Architectuur een gebruiksaanwijzing. Theorie, kritiek en geschiedenis sinds 1950 volgens Geert Bekaert [Architecture, a User's Manual. Theory, History and Criticism of Architecture Since 1950 According to Geert Bekaert], Ghent, A\&S Books. VAN GERREWEY, C.; VERSCHAFFEL, B.; CLEPPE, B. 2013. bOb Van Reeth Architect, Brussels, A+editions / Bozar Books. DOI: https://doi.org/1854/ LU-3257441

VAN REETH, B. 1983. "De herinnering aan wat nooit heeft bestaan" [The Memory of What Never Was], in B. Van Reeth and G. Bekaert, Op. cit.: 141-175.

VAN REETH, B. 1985. "bOb Van Reeth in gesprek met Mil en Marc De Kooning en Dirk Jaspaert, 1983-1984" [bOb Van Reeth in Conversation with Mil and Marc De Kooning and Dirk Jaspaert, 1983-1984], Vlees en Beton, $n^{\circ}$ 3: n.p.

VAN REETH, B.; BEKAERT, G. 1983. bOb Van Reeth. Teksten van en over, Ghent, R.U. Gent - Faculteit der Toegepaste Wetenschappen [though uncredited, this book was edited by Mil De Kooning].

VERSCHAFFEL, B. 1993. “'A Architectuur is (als) een gebaar'. Over het 'echte' als architecturaal criterium" [Architecture Is (as) a Gesture. On 'Authenticity' as an Architectural Criterion], in $\mathrm{H}$. Heynen (ed.), Op.cit.: 67-80. DOI: https://doi. org/854/LU-327656 [Translated in English as 2001. Architecture Is (as) a Gesture, Lucerne. Quart Publishers. DOI: https:// doi.org/1854/LU-327652].

VERSCHAFFEL, B. 2013. "bOb Van Reeth as Designer: On the Importance of Complexity and a Sense of the Elementary", in Van Gerrewey et al. Op.cit.: 51-57. DOI: https://doi.org/1854/ LU-3259011 